\title{
A Semantic and Semiotic Study of Viewpoint in Mam and Zin ${ }^{1}$
}

\author{
Sherzad Shafi' BARZANI' \& Jihad Shukri RASHID ${ }^{3}$
}

Received: Jul 03, 2019 Reviewed: Jul 09, $2019 \quad$ Accepted: Jul 21, 2019

\begin{abstract}
The domain of semantic_semiotic studies can be very vast and such kind of studies is applicable as an analytical tool and foundation theory for analyzing narratives and fictions. Since the point of view is a collection of techniques which enables the narrator to create diversity in the processing of the text, therefore the selection of the viewpoint by the narrator has a great function in the narrative. In this research the researches try to scrutinize the point of view and its kinds in the poetic narrative of Mam and Zin by using the mechanism of semantic semiotic approach. The research also tackles with different kinds of viewpoints in a descriptive analytical method in accordance with the poetic template of the narrative. The outcome of the research indicates that the way of using the different kinds of viewpoint in addition to visualizing the skills and abilities of the poet, also makes the narrative more attractive and influential. All in all this semantic_semiotic study of the narrative indicates that the literary creation is the result of a narrating activity in which the text of the narrative of this research includes such kind of narrating forms.
\end{abstract}

Keywords: Semantic, semiotic, viewpoint, Mam and Zin.

\section{Recommended citation:}

Barzani, S. S. \& Rashid, J. S. (2019). A Semantic and Semiotic Study of Viewpoint in Mam and Zin. International Journal of Kurdish Studies 5 (2), 473 - 481 DOI: 10.21600/ijoks.586073

\footnotetext{
${ }^{1}$ This article was presented as a report in ECLSS conference on 27th of April 2019 in Antalya, Turkey.

${ }^{2}$ Asst. Prof. Dr., Salahaddin University, Erbil, Iraq, E-mail: sherzad.barzan@su.edu.krd, ORCID ID: 0000-0002-4784-0352

${ }^{3}$ Asst. Prof. Dr., Salahaddin University, Erbil, Iraq, E-mail: jihad.rashid@su.edu.krd, ORCID ID: 0000-0003-1038-8291
} 


\section{Introduction}

The narrator is a person who narrates the narrative whether it has been created by another person or by the narrator (Berger, 1380: 21). The job of the narrator is to narrate the text of the narrative. The narrator is someone who selects the events, presses, expands and by a continuous selection forms the narrative. The narrator hides or reveals the thoughts of the characters and he has a special attitude toward the motif of the narrative (Akhlaqi, 1377: 207). All the elements that shape a narrative like viewpoint, tone, setting and so on leads us to the narrator. The narrator embodies the judgments within the narrative whether to expand a attitudes of a character or not (Todorrove 1379, 71-2). The text of the narrative takes its existence from the narrator and without narrator there will be no narrative. According to Edmond Cros from a semiotics point of view the text of the narrative is a sign in which the writer is the sender of the sign and the reader is the receptor of it. Within this sign there is another sender who is the narrator that sends another sign for the receptor to shape the narrative (Akhlaqi, 1377: 208).

There is a relationship between the narrator and what he narrates which is called the point of view. The point of view is a perspective that the narrator through it sees the events of the narrative (Akhlaqi, 1377: 209). The viewpoint includes two major fields: the field of eye and the field of thought. The field of eye shows the perspective of narrator toward the events and illustrates the chronological distant of events to the narrator. In the field of eye the narrator deals with the position in which he sees the events e.g. whether he sees them from above, sides, within or outside the narrative. The field of thought indicates the feelings of the narrator toward the narrative. With the usage of vocabulary and tone one can realize the narrator's feelings and attitudes (Akhovat, 1371: 205-7).

The point of view is a basic and important element in the structure of the narrative. The selection of the suitable point of view in writing the narratives is very crucial, since in one hand it demonstrates the feeling and the approach of the narrator towards the motif and the content of the narrative and in the other hand it has a great impact on the other elements of the narrative like character, scene and dialogue.

\section{The Objective of the research}

Semiotics is the science of signs and the study of sign systems in different branches. The language as one of the sign systems has a high potentiality to be investigated for researches. The literature which is the best manifestation of language is also a remarkable field for such kind of studies. For this reason the poetic narrative of Mam and Zin can be a perfect choice for a semiotics analytical study. The main objective of this essay is: A Semantic and Semiotic Study of Viewpoint in Mam and Zin. 


\section{The Style of Research}

This research is based on a descriptive-analytical approach in which the different viewpoints in the poetic narrative of Mam and Zin would be scrutinized.

\section{The Theoretical Topics}

\section{Semiotics}

According to Merriam Webster Dictionary semiotics is: "a general philosophical theory of signs and symbols that deals especially with their function in both artificially constructed and natural languages and comprises syntactic, semantics, and pragmatics."( Merriam) The relation between semiotics and other branches of Linguistics is described by C. W. Morris in the following way: "semantics: the relationship of signs to what they stand for, syntactic (or syntax): the formal or structural relations between signs, pragmatics: the relation of signs to interpreters."(Chandler, 1995: 3)Semiotics is "an open road that leads to semantics"(Ahmadi, 1388: 40) and also the sign in semiotics "is not only a thing stands for another thing but it is an entity which needs interpretation."(Lechet, 1383: 190-3)

The interpretation of the signs is an approach which is used in literature and history and "it bridges the literature and linguistics" (Fischer \&Muller, 2003: 1). Consequently semiotics is an approach for analyzing and scrutinizing of the language in diverse texts which need a structural research. As the structuralists mention the existing of the text is based on the harmony among its elements, in semiotics as well the value of each sign is determined by the harmony among the other signs. With such kind of attitude the narratives can be described and analyzed by semiotics.

\section{Semiotics and Semantics}

Semiotics is a scientific tool which can be used to study the forming structure of Semantics in discourse. The semiotics-semantics study unlike structural semiotics which sees the signs in some closed templates, it sees the signs in a dynamic, flexible, fluid, changeable and multi dimensional entity. Therefore in this process semiotics shows the semantics as a dynamic, flexible, fluid and multi-dimensional entity. This fluid relationship which is formed by intersecting of two axis of quality and quantity creates a new semantic values. Ferdinand de Saussure was the first linguist who introduced value into the linguistic system. He believes that value is achieved by divergence and semantic is a different product that exists between words (Saussure, 1380: 176-77). Therefore the value can be equivalent to the smallest unit of semantic which is the product of semantic confrontation (Shairi, 1388: 223). 


\section{View Point and its Types in Discourse}

In discourse the points of view according to Jacques Fontanille format will be categorized into different types that the narrator based on them transfers more or less details to the reader either directly or indirectly. Shairi classifies them to different types which they can be applied on Mam and Zin. The different types of points of view according to shairi are shown in the following figure:

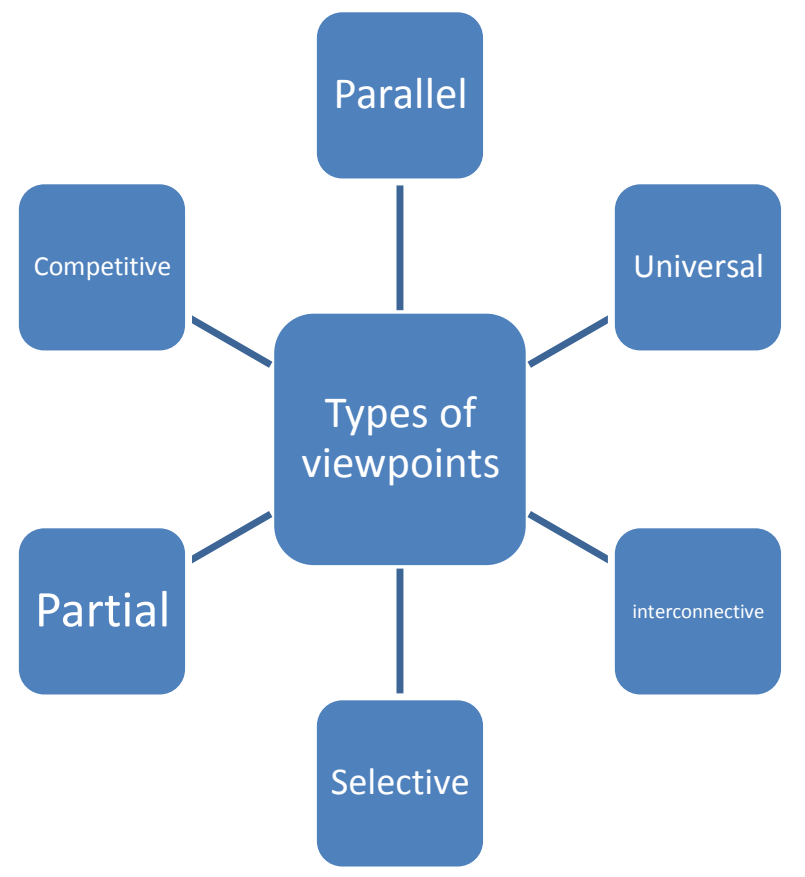

\section{The Universal point of View}

This type of point of view is based on wholeness approach. In other words it is an overview. In this approach the narrator has a general look toward a list of events. The narrating type of looking, observing, scrutinizing belongs to this type of viewpoint (Shairi, 1389:80). This overview approach in Mam and Zin shows an internal state in which the narrator sees the love as the headspring of life and the only way to reach the beloved and his God; toward these subjects he has a list like look:

Cupbearer! Leave me alone as I am still handy

Drunk, wine-drinking and tipsy

We lovers may worship the wine

Yet we are already drunk with divine wine

It is not red as your wine

It is the grace of God 
Cupbearer! For God's sake give me right away

A cup of wine that you served yesterday

To taste one sip only

Providing joy enough till the end, truly

( Saadalla, 151)

\section{Inter-connective Point of View}

This kind of viewpoint is a "cognitional sight which shows the different phases of a thing one after another. The inter-connective point of view is a synthetic outlook based on successive look (Shairi, 1388: 83). In this viewpoint for showing the different corners of a house, all its sections seen in an over-viewing look such as curtains, pictures and so on. In Mam and Zin the narrator has used this point of view in order to describe the scenes and the events of the epic. The narrator by the means of inter-connective point of view refers to the different groups of people in the new year's celebration such as sages, pedestrians, infantries, cavalries, managers, clerks, masters, singers, hangers and so on which shows and incarnates a different aesthetic dimension of signs in the narrative. All of these phases are arranged in a connective way like the following lines:

So much magnified and round

This way made and repeated

Some are slow and some are fast

Some are easy and some are hard

Some are managing and some are managed

Some are forthcoming and some predestined

Some are clerks and some are masters

Some are singers, some are hangers

Some worship the sun, some worship the moon

Some banish the grief, some attract the boon

( Saadalla, 53 )

In the following lines as in the previous lines the narrator has used the inter-connective point of view to show how the lamenting is done on the occasion of Mam's death.

Screaming, lamenting and weeping

Noise-making, and distressing- calling 


\section{The people of Botan, old and children \\ Women and girls, bride and maiden \\ Personalities, great and high ranking \\ Clerks, boys and uncaring}

Not one individual was happy in the city

Everyone was confused and dizzy.

( Saadalla, 213 )

In this viewpoint, the narrator in his discourse has taken to his consideration the different groups of people who are mourning for Mam.

\section{Selective Point of View}

This viewpoint is based on selecting the best paradigm of a state or situation in which by selecting the best sample the search comes to an end. "When the best paradigm is selected all the other paradigms which are less important will be neglected. The selected paradigm is perfect" ( Shairi, 1388: 86). The narrator in Mam and Zin, for highlighting love has used the selective point of view. He has shown the good and bad sides of human beings. By coming to the tragic ends of the heroes the narrator does not leave the readers alone in their judgments and the narrative is not neutral, but he tries to induce his ideology and feelings to the reader:

\section{Cupbearer! Leave me alone as I am still handy}

Drunk, wine-drinking and tipsy

We lovers may worship the wine

Yet we are already drunk with divine wine

( Saadalla, 151)

Or elsewhere he says:

What else should I say? I do not know

My tongue does not know what to say

( Saadalla, 147 )

It is worth mentioning that the "narrative I" is a method in narrating in which the narration is left to an "I". This "I" retells the real and historical event in which either he is the creator and the hero or the observer and witness who has a close relationship with the narrating "I". What is very crucial in this method is this reality that sometimes the narrator appears in narrating and preaches for himself and the readers:

Let us go back to the previous story

To people suffering from the love agony 
( Saadalla, 48 )

Of course the narrator should not come in between all of a sudden; he must be silent and let the character to act by themselves. Sometimes it happens that Nezami and Khani who are both storytellers and poets go so deep into the bottom of their stories that forget their own position in the process of narrating.

\section{Partial or Special Point of View}

In partial viewpoint the general and international approaches has no place, it is mostly focuses on micro and special views. It selects a part of something and then investigates it deeply. This micro and tiny observation of the things makes this point of view partial or special (Shairi, 1389, 83). In khani's epic of Mam and Zin there is a sensory- cognitive relationship. In the epic, Zin is the center of all the sensual, cognitive actions under the impact of Mam's love, her exterior and interior situation has changed dramatically. In the following lines she explains the consequences of Mam's love:

My face that was a purple-red flower

Turned sallow the shade of saffron

Full of regrets and unfortunate am I

Forsaken by that warbler, wilted have I

( Saadalla, 139)

On the contrary sometimes Mam is the center of all sensual and cognitive actions and the Zin's love makes physical and spiritual changes in him:

That dignified mountain, that calm sea

Love may make light with lunacy

Thus it came to pass that Mam, patient and unlucky

Who was weakened excessively, his health poorly

( Saadalla, 143 )

As it is clear in the above mentioned lines the narrator has scrutinized the theme of love in the main characters of the epic.

\section{Parallel Point of View}

In the parallel point of view, "there are two types of cognitive approaches without dominating each other or damaging one another" (Shairi, 1388: 88). The Most often this viewpoint is used 
in debates in which "the two types go with each other in a parallel lines without any domination or damaging of one another" (Karbalayee, 1391: 403). In Mam and Zin'S epic there are two different speeches that go onward in parallel lines. This debate is between Moth and Candle that represent Mam and Zin the dialogue between them goes on in parallel lines:

During the scorching of the feather

They said a few words to each other

The moth said: "You are a good guide" The candle answered "You are a good friend"

The moth said: "You are a sign on the road"

The candle answered "You are a gift of life"

The moth said: "You are the light of the heart"

The candle answered "You are the fire in my bosom

The moth said: "You are the right cure"

The candle answered "You are a tender heart"

( Saadalla, 202-3 )

As it is mentioned above the debate is between the moth and the candle, the dialogue between them is equal, parallel and interacting.

\section{Competitive Point of View}

In this type of viewpoint "there are two or more cognitive approaches which compete each other and each one of them interrogate the other without anticipating any clear result. The results can be achieved only in the process of discourse" (Shairi, 1388: 89-90). In the Mam and Zin's epic the narrator has used this point of view to indicate the inactive or sensual cognitive which are rooted in the internal side of the characters. Somewhere these feelings go in the opposite directions and compete against each other. The best example in the epic is the contrast of the feelings of true and untrue love between Mam and Tajdin:

He said: "Get up brother! Out of bed

Stop this moaning and suffering

We are lions, they are gazelles

It is shameful we are groaning at their hands"

Mam was the quintessence of total lover He said:

"You may be a little troubled brother! 
Not a spot is free of hurting

Is it any worth you ask why I am moaning

The heart is now the home of settling passion

In this condition, in this empty position

I may be supplanted, no wonder

And have the form, not the essence of matter

\section{( Saadalla, 64 )}

The above lines show the conflict between the two approaches toward the love. In these lines the sensual- cognitive conflict goes on between the true love and the untrue love which leads to compete each other. This competition brings about an active reflection which guides Mam toward some supernatural forces that are beyond Mam's understanding in the process of seeing this metaphysical power Mam compares and contrasts the true and untrue love of himself and Tajdin. This is the beginning of Mam's self-knowledge process and the climax of the epic.

\section{Conclusion}

The results of this research shows that the narrator in Mam and Zin's epic tries to illustrate his internal state by international point of view in a way to indicate that love is an eternal capital and the source of life. Love is also a way that leads to God and spirituality. In the epic, for explaining the events and the scenes the narrator uses inter-connective point of view by which he describes the way that people come together on the occasion of Newroz for celebrating the New Year. The narrator has also used this point of view lamenting and mourning ceremonies. In the partial point of view the narrator focuses on the effects of love on the main characters of the epic Mam and Zin. The narrator has used the parallel point of view for debates and dialogues between two characters in the epic which go side by side in a parallel way without damaging or overshadowing each other. And finally the narrator is very successful by using the competitive point of view to explain the inactive or sensual cognitive situations in which the internal feelings of the characters are rooted.

\section{References}

Ahmadi, Babak, (1388). From the Symbols to Text. $9^{\text {th }}$ Ed. Tehran: Nashre Markaz.

Akhlaqi, Akbar, (1371). The Grammar of Fiction. $1^{\text {st }}$ Ed. Esfahan: Nashre Farda.

Asa Burger, Arthur, (1996). Narratives in popular culture, Media, and Everyday life. London: Sage Publications.

Saussure, Ferdinand, (1380). Foundations of Structuralism in Linguistics. Trans. Kurosh Safavi on Structuralism, post-Structuralism and literary studies. Tehran: Hozeh Hunari. 
Shaieri, Hamid Reza, (1389). Analysis of Sign and semiotics of Discourse. $2^{\text {nd }}$ Ed. Tehran: samt. "Reviewing Semiotic and Semantic style of negotiations in Café Transit Movie: from Catastrophe to aesthetics" from the Articles of the $4^{\text {th }}$ Forum of Art semiotics on Cinematic Thought. No. 188. PP. 217-234.

Shaieri, Hamid Reza and Taraneh, Wafaie, (1388). A Way to Semiotic-Semantic Liquidness. $1^{\text {st }}$ Ed. Tehran Elmi va Farhangi.

Karbalaie, Sadeq and Mahnaz, (1391). The Viewpoint in Nizami Ganjavi's Khosrow and Shirin. A semiotic and sematic approach. from the Articles of the $2^{\text {nd }}$ Forum with a semiotic and sematic approach. $1^{\text {st }}$ Ed. Tehran: Khaneh Ketab. PP. 393-405.

Lechte, John, (1994). Fifty Key Contemporary Thinkers. London: Routledge.

Chandler, Daniel. (1995). Semiotics for Beginners. Pdf. London: Routledge.

http://s3.amazonaws.com/szmanuals/bb72b1382e20b6b75c87d297342dabd7

Date of Access 2/3/2018.

Semiotics

https://www.merriam-webster.com/dictionary/semiotics Date of Access 2/3/2018. 